Please do not destroy or throw away this publication. If you have no further use for it, write to the Geological Survey at Washington and ask for a frank to return it

UNITED STATES DEPARTMENT OF THE INTERIOR

Ray Lyman Wilbur, Secretary

GEOLOGICAL SURVEY

Director

Professional Paper 170-C

\title{
A MIOCENE FLORA \\ FROM GRAND COULEE, WASHINGTON
}

BYY

EDWARD WILBFR BERRY

Shorter contributions to general geology, 1931

(Pages 31-42)

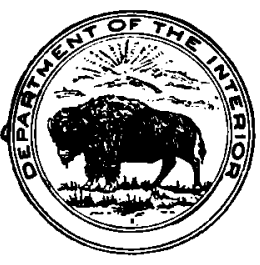

UNITFD STATFS

GOVERNMENT PRINTING OFFICF

WASIIINGTON : 1921 


\section{ILIUUSTRATIONS}

Plates 11-13. Miocene flora from Grand Coulee, Wash _... Page

Figdre 3. Restoration of Paliurus hesperius 


\title{
A MIOCENE FIORA FROM GRAND COULEE, WASHINGTON
}

\author{
By Edward Wilber Berry
}

\section{INTRODUCTION}

The fossil plants described in the present report were collected at the north end of Grand Coulee during the summer of 1927 by Messrs. T. A. Bonser, F. A. Roberts, and Walter Bruce, of Spokane, and F. W. McCann, of Coulee City. The locality is in the big bend of the Columbia River near the northern boundary of Grant County, Wash., about 85 miles west of the plantbearing Latah sediments around Spokane. The outcrop in Grand Coulee is about the same distance east of the crest of the Cascade Mountains, about 100 miles northeast of the plant beds at Ellensburg, which are of approximately the same age, and some 200 miles west of beds in Idaho yielding a similar flora and assigned to the Payette formation by Knowlton and others.

The material in which the plants occur is of two not very dissimilar sorts. One is a buff diatomaceous matrix which I am informed occurs as boulders in glacial till. The other is a ferruginous clay found in place, which might well be a more silty phase of the diatomaceous rock.

The following details concerning the geography and geology of the plant-bearing deposit were furnished by Mr. T. A. Bonser, of the Spokane Public Museum:

The clay deposit in which the fossil leaves occur is at the extreme north end of the coulee, just at the top of the hill that leads down to the Columbia River. It is on a level with the floor of the north end of the coulee and about 500 or 600 feet above the river. The winding road from the floor of the coulee to the river is about 2 miles long, but the actual distance from the deposit to the river is not more than half a mile. The deposit rests upon granitic rocks, just as the Latah formation does in the neighborhood of Spokane. Detached clay boulders in a glacial till about half a mile down the hill along the road also contained fossil leaves.

The principal exposure is about 200 yards long and 15 to 20 feet deep at the highest point, but there is evidently a much greater depth below the level of the road. On a ranch about a quarter of a mile northwest of the exposure and about 50 to 80 feet higher fossil leaves were found in an excavation for a cellar.

To the southeast of the plant locality there is a basaltic rock wall standing 800 to 1,000 feet above the floor of the coulee, and several miles southwest is the locally famous Steamboat Rock, about 800 or 1,000 feet high.

The plant material is not as abundant, as varied, or as well preserved as that of the Latah formation at Spokane, Wash., but it is of considerable interest in that it furnishes several species that are new to the flora of our western Miocene. In addition, it greatly extends the range of many of the already known species and shows that essentially similar physical conditions $63012^{\circ}-31$ prevailed over a very great area of country in Idaho, Washington, and Oregon during late Miocene time.

In all 55 different types of plants have been recognized in the material from Grand Coulee, or about onethird the number described from the Latah formation. Several of these, however, are not distinct species but comprise such things as maple keys, taxodium cone scales and staminate catkins, oak acorns and cupules, poplar bud scales, and a sycamore flower head, which undoubtedly appertain to the associated botanic species based on foliage.

They represent 34 genera in 25 families and 16 orders. Five of the genera are gymnosperms; the remainder are angiosperms. All but one of the angiosperms are dicotyledons, and all of these except the Viburnum belong to the choripetalous division. The most abundant individually are the leaves of birch, chestnut, elm, poplar, and oak. Seven different species of oaks have been named, but it should be pointed out that there has probably been an overrefinement in species due to the personal equations of the different students who have worked on Miocene floras, to the great variability of the leaves in this and other genera, such as Betula, Ulmus, and Acer, and to the practical impossibility of drawing specific lines throughout where large amounts of material are available for study.

The flora thus far discovered at Grand Coulee does not add any thing to the conclusions regarding environmental conditions, which were set forth at some length in my discussion of the Latah flora. ${ }^{1}$ Most of the genera represented no longer occur in this general region. Many have become entirely extinct in western North America since the Miocene epoch, and a few, such as Glyptostrobus and Paliurus, are confined to the Old World in existing floras.

Inasmuch as the flora discovered at Grand Coulee can be rather closely correlated as to age and as it is but a small part of the Miocene flora of western North America as a whole, an attempt to discuss the broader questions of its antecedents, environment, extinction, and bearing on the geologic history of the region does not seem worth while. This has been done to some extent in connection with the Latah flora, and permanent results can be reached only after the large amount of material from the Pacific States which is being studied by Chaney, me, and others has been fully worked up and published.

\footnotetext{
1 Berry, E. W., A revision of the flora of the Latah formation: IT. S. Geol. Survey
} P'ror. Paper 154, pp. 233-234, 1929. 


\section{AGE OF THE GRAND COULEE PLANTS}

The Grand Coulee flora can be correlated with great precision. Of the 55 objects enumerated in the accompanying table of distribution 48 occur in the Latah flora around Spokane, those that have not as yet been recorded from the Latah being Glyptostrobus europaeus, Hicoria washingtoniana, Juglans egregia, Lysichiton washingtonense, Platanus flower head, Pielea miocenica, Quercus mccanni, and Vitis bonseri. Of these the Hicoria, Lysichiton, Ptelea, Quercus, and Vitis are new and are likely to turn up at any momen ${ }^{\prime}$ in the Spokane area. Moreover, the Platanus flower head, the fragment of a Lysichiton spadix, and the Vitis seed may be classed as more or less exceptional and accidental, both as to original preservation and as to subsequent discovery. Juglans egregia is a species of the California Miocene, and I have seen it in collections from Idaho. The Glyptostrobus has thus far unaccountably not been found in the Spokane region, but it will probably turn up there eventually, for it is not uncommon in the western Miocene and is present in the Payette formation of Idaho. Consequently there can be no doubt that the Grand Coulce flora is of the same age as the Latah flora of eastern Washington.

Next to the practical identity of the Grand Coulee flora with that of the Latah the greatest resemblance is shown to floras recently collected by Kirkham in west-central Idaho and submitted to me for identification. The localities with lists of species have been described in a recent paper by Kirkham and Johnson. ${ }^{2}$ These authors consider the Latah a series rather than a formation and extend the name to include not only their Idaho localities but the Grand Coulee locality, which they had heard of through Mr. McCann, of Coulee City. In the accompanying table of distribution I have listed the Idaho occurrences as from the Payette formation, though I believe the plant-bearing beds in Idaho represent several horizons, and I question the propriety of using the name Latah there. If all the disconnected basins of sedimentation associated with the Columbia River lava are to be called by a single name, which I do not believe is the proper procedure, there are other and earlier names than Latahfor example, Payette (1898), Ellensburg (1900), and Mascall (1901). But it is not clear that the Payette beds are more than partly equivalent to the Latah. Certain plants from the Idaho section suggest a Pliocene age, and there are some elements identical with the Bridge Creek flora which do not occur in the Spokane area and which suggest that a part of the Idaho section is older than the typical Latah. This

\footnotetext{
Kirkham, Y. R. D., and Johnson, M. M., The Latah formation in Idaho: Jour. Geology, vol. 37, pp. 483-5014, 1924.
}

is not the place to attempt a discussion of these Idaho floras beyond making clear the qualification required by the present state of our knowledge in comparing the Grand Coulee plants with those identified or reported from Idaho localities.

Twelve of the Grand Coulee plants are recorded from the Mascall formation of Oregon, and it seems probable that this number will be increased when Chaney completes his revision of this standard flora and especially when the personal equations of various students in connection with such genera as Acer, Liquidambar, Betula, and Ulmus are taken into account.

Seven of the Grand Coulee plants are recorded from the Eagle Creek formation, and these seem to me to indicate that the Eagle Creek is somewhat younger than it is generally held to be.

Only four of the Grand Coulee plants are recorded from Florissant, Colo., but of these the Populus and Liquidambar are significant. As the Grand Coulee flora is practically identical with that from Spokane its real similarity to the Florissant flora must be greater than it seems, for the Spokane flora has a great many elements in common with that at Florissant and the later and unpublished collections from Spokane indicate that this resemblance is still stronger.

I consider that five of the Grand Coulee plants are represented in the flora from the St. Eugene silt of the Kootenay Valley, in British Columbia, described by Hollick. ${ }^{3}$ I have already commented briefiy on this, ${ }^{4}$ and a more complete discussion is not called for in the present connection, but the great abundance of Cebatha heteromorpha in both floras seems to me to settle beyond dispute the age of the Canadian deposit.

The position to be assigned to the Grand Coulee flora in the world section of the Tertiary is tied up with the results of the study of the other scattered Miocene floras of the western United,States. In my published account of the Latah flora I stated my belief that although the Latah might be as old as middle Miocene it was more probably upper Miocene. In the several years that have elapsed since the manuscript for that, account was prepared I have studied numerous additional collections from the Spokane area, and nothing I have seen in these later collections has served to modify this statement. On the other hand, the evidence for an upper Miocene age is constantly becoming more convincing. This being the case for the Spokane flora, so much more extensive and better preserved than the Grand Coulee flora, the same conclusion holds equally for the Grand Coulee.

? IIollick, Arthur, The flora of the St, Eugene silts, Kootenay Valley, Briditil Columbia: New York Bot. Garden Mern., vol. 7 , pp. 389-464, pls. 24-47, 1927.

+ Berry, E. W., The age of the st. Fugene silt in the Kootenay Valley, British Columbia: Roy. Soc. Canada, sec. 4, 'T'rans., 3d ser., vol. 23, ply. 47-48, 1923. 
Flora from Grand Coulee, Wash., compared with Miocene floras from other localities

\begin{tabular}{|c|c|c|c|c|c|c|c|c|c|c|}
\hline & $\begin{array}{c}\text { latah for- } \\
\text { mation, } \\
\text { Spokane } \\
\text { and vicinity }\end{array}$ & $\begin{array}{c}\text { Mascall } \\
\text { formation }\end{array}$ & $\begin{array}{l}\text { Ellensburg } \\
\text { formation }\end{array}$ & $\begin{array}{l}\text { Payet te for- } \\
\text { mation of } \\
\text { ldaho }\end{array}$ & $\begin{array}{l}\text { Bricige } \\
\text { Creek Inora }\end{array}$ & $\begin{array}{l}\text { Eagle } \\
\text { Creek for- } \\
\text { malion }\end{array}$ & $\begin{array}{l}\text { Miocene of } \\
\text { Yellow: } \\
\text { stone Park }\end{array}$ & $\begin{array}{c}\text { Florissant, } \\
\text { Colo. }\end{array}$ & California & $\begin{array}{l}\text { St. Eugene } \\
\text { silt, Brititisb } \\
\text { Columbis }\end{array}$ \\
\hline $\begin{array}{l}\text { Acer merriami } \ldots \\
\text { Acer, fruit }\end{array}$ & $\stackrel{x}{x}$ & & & $x$ & & & & & & \\
\hline Betula heteromorpha. & $\hat{x}$ & & & & & $x$ & & & & ?) \\
\hline Betula largei & $x$ & & & $x$ & & & & & & \\
\hline Carpites boraginoides. & $x$ & & & $x$ & & & & & & \\
\hline Carpites ginkgoides... & $x$ & & & & & & & & & \\
\hline Cassia spokanensis & $x$ & & & & & & & & & \\
\hline Castanea castaneaefoli & $x$ & $x$ & & $x$ & & & & & $x$ & \\
\hline Cebatha heteromorpha & x & & & $x$ & & & & & & \\
\hline Euonymus knowltoni- & $x$ & & & $x$ & & & $-\ldots$ & & & \\
\hline Ficus washingtonensis. & $x$ & & & $x$ &.- & & & & & \\
\hline Ficus interglacialis _...- & $x$ & & & $x$ & & & & & & \\
\hline $\begin{array}{l}\text { Glyptostrobus europa } \\
\text { Gordonia hesperia... }\end{array}$ & $x$ & & & $x$ & & & & & & \\
\hline Hicoria washingtonian & & & & & & & & & & \\
\hline Juglans egregia. & & & & & & & & & & \\
\hline Laurus similis. ..... & $x$ & & & $x$ & & $x$ & & & & \\
\hline Libocedrus praedecurrer & $x$ & (?) & & $x$ & & & & & & \\
\hline $\begin{array}{l}\text { Liquidambar, fruits } \\
\text { Lysichiton washingtonense }\end{array}$ & $x$ & $x$ & & $x$ & & $x$ & $-\cdots$ & $x$ & $x$ & \\
\hline Menispermites latahensis & $\bar{x}$ & & & & & & & & & \\
\hline Nyssa hesperia & $x$ & & & $x$ & & & $-\ldots$ & & & \\
\hline Nyssa magnifica $\ldots . . .$. & $x$ & & & & & & --- & & & \\
\hline Paliurus hesperius & $x$ & & & $x$ & & & -- & & & \\
\hline $\begin{array}{l}\text { Phyllites amplexicaulis } \\
\text { Phyllites couleeanus }\end{array}$ & $x$ & & & 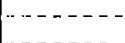 & & $\cdots$ & -- & & & \\
\hline $\begin{array}{l}\text { Phymintes coureeanus } \\
\text { Platanus aspera }\end{array}$ & $x$ & & & & & $x$ & & & & \\
\hline Platanus dissecta & $x$ & $x$ & $x$ & $x$ & & & & & $x$ & (?) \\
\hline Platanus, flower head. & & & & & & & & & & \\
\hline Populus lesquereuxi. . . & $x$ & & & & 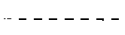 & $-\ldots$ & $-\ldots$ & $x$ & & \\
\hline Populus lindgreni $\ldots \ldots$ & $x$ & & $x$ & $x$ & & & & & & \\
\hline Populus washingtonensis $\ldots$ & $x$ & & $\cdots$ & $\bar{x}$ & & & --- & & & \\
\hline $\begin{array}{l}\text { Populus, bud scales } \\
\text { Prumus rusti }\end{array}$ & $x$ & & & $x$ & & & & & & \\
\hline $\begin{array}{l}\text { Prumus rusti } \\
\text { Ptelea iniocenica. }\end{array}$ & & & & & & & & & & \\
\hline Quercus eognata & $x$ & & & $x$ & & & -- & 烈- & & \\
\hline Quercus mecanni_.-. & & & & & & & -1 & & & $\ldots$ \\
\hline Quercus merriami _._..... & $x$ & $x$ & & & & $x$ & -- & & & $-\ldots-n$ \\
\hline Quercus payettensis? . . . & $\times$ & - & - & $x$ & & & -- & & -- & ----- \\
\hline $\begin{array}{l}\text { Quercus pseudolyrata } \\
\text { Quercus simulata }\end{array}$ & $x$ & $x$ & & $x$ & & $x$ & & & & \\
\hline Quercus treleasi & $x$ & & & $\hat{x}$ & & $-\ldots$ & $\begin{array}{ll}-1--1 \\
-1-n-1\end{array}$ & (n) & & 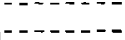 \\
\hline Quercus, acorns and cupules & $x$ & & $\ldots \ldots$ & $x$ & & & -....- & 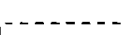 & & $\ldots \ldots$ \\
\hline $\begin{array}{l}\text { Ribes fernquisti } \\
\text { Sequoia langsdorfii }\end{array}$ & $\stackrel{x}{x}$ & & & $x$ & ---- & -- & ------ & ----- & & ------ \\
\hline $\begin{array}{l}\text { Sequoia langsdorfi1 } \\
\text { Sophora alexanderi }\end{array}$ & $\hat{x}$ & $x$ & & $\ddot{x}$ & & & & $x$ & & \\
\hline Sophora spokanensis & $x$ & & $\ldots \ldots$ & $x$ & $-\ldots \ldots$ & $\ldots$ & - n- & & & 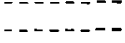 \\
\hline Taxodium dubium & $x$ & $x$ & $-\cdots-1$ & $x$ & $\cdots-\cdots$ & $\ldots \ldots$ & $-\ldots$ & $x$ &.-- & $-\ldots$ \\
\hline $\begin{array}{l}\text { Taxodium, cone scales } \\
\text { Taxodium, staminate aments }\end{array}$ & $x$ & $x$ & - n & & & & & $-\infty$ & & \\
\hline Tsuga latahensis & $x$ & & & & & & 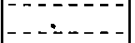 & - & & 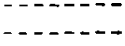 \\
\hline Ulmus speciosa & X & & & $\frac{x}{x}$ & $\cdots$ & $x$ & $-\cdots-\cdots$ & $----\cdots$ & & $-\ldots$ \\
\hline $\begin{array}{l}\text { Umbellularia lanceolata }- \\
\text { Viburnum fernquisti.-- }\end{array}$ & $x$ & & & $x$ & & & & 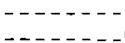 & & \\
\hline Vitis bonseri & & & & & & & & & & $-\ldots .$. \\
\hline
\end{tabular}


A systematic list of the species identified in the Grand Coulee flora is given below, as it has not seemed necessary to describe any except those that are new or afford some addition to our knowledge.

\section{Coniferophyta:}

Pinales:

Cupressinaceae:

Sequoia langsdorfii (Brongniart) Heer.

Taxodium dubium (Sternberg) Heer.

Taxodium, cone scales.

Taxodium, staminate aments.

Libocedrus praedecurrens Knowlton.

Glyptostrobus europaeus (Brongniart) Heer.

Pinaceae:

Tsuga latahensis Berry.

Spermatophyta:

Angiospermae:

Monocotyledonae:

Arales:

Araceae:

Lysichiton washingtonense Berry.

Dicotyledonac:

Choripetalae:

Juglandales:

Juglandaceac:

Juglans egregia Lcequereux.

Salicales:

Hicoria washingtoniana Berry.

Salicaceae:

Populus lesquereuxi Cockercll.

Populus washingtonensis Knowlton.

Populus lindgreni Knowlton.

Populus, bud scales.

Betulaceae:

Betula heteromorpha Knowlton.

Betula largei Knowlton.

Fagaceae:

Castanea castaneacfolia (Unger) Knowlton.

Quercus payettensis Knowlton?

Quercus pseudolyrata Lesquercux.

Quercus merriami Knowlton.

Quercus cognata Knowlton.

Quercus mecanni Berry.

Quercus, acorns and cupules.

Quercus treleasi Berry.

Quercus simulata Knowlton.

Urticales:

Ulmaceac:

Ulmus speciosa Newherry.

Moraceae:

Ficus washingtonensis Knowlton.

Ficus interglacialis Hollick.

Platanales:

Platanaceae:

Platanus dissecta Lesquereux.

Platanus aspera Newberry.

Platanus, flower head.

Ranales:

Menispermaceae:

Menispermites latahensis Berry.

Cebatha heteromorpha (Knowlton)

Rosales:

Berry.

Grossulariaceae:

Ribes fernquisti Berry.

Hamamelidaceae:

Liquidambar, fruits.
Spermatophyta-Continued.

Angiospermae-Continued.

Dicotyledonae-Continued.

Choripetalae-Continued.

Rosales-Continued.

Drupaceae:

Prunus rusti Knowlton.

Caesalpiniaceae:

Cassia spokanensis Berry.

Papilionaceae:

Sophora alexanderi Knowlton.

Geraniales:

Sophora spokanensis Knowlton.

Rutaceae:

Ptelea miocenica Berry.

Sapindales:

Celastraceae:

Euonymus knowltoni Berry.

Aceraceae:

Acer merriami Knowlton.

Acer, fruit.

Rhammales:

Rhamnaceae:

Paliurus hesperius Berry. Vitaceac:

Vitis bonseri Berry.

Parietales:

Ternstrocmiaccae:

Gordonia hesperia Berry.

Laurales:

Lauraceac:

Laurus similis Knowlton.

Umbellales:

Umbellularia lanceolata Berry.

Cornaceae:

Nyssa magnifica Knowlton.

Nyssa hesperia Berry.

Gamopetalae:

Rubiales:

Caprifoliaceae:

Viburnum fernquisti Berry.

Position uncertain:

Carpites ginkgoides Knowlto

Carpites boraginoides Knowlton.

Phyllites amplexicaulis Knowlton.

Phyllites couleeanus Berry.

\section{SYSTEMATIC DESCRIPTIONS \\ Phylum CONIFEROPHYTA \\ Order PINALES \\ Family CUPRESSINACEAE}

Genus TAXODIUM L. C. Richard

Taxodium dubium (Sternberg) Heer

Plate 11, Figure 1

The more or less complete synonymy of this ubiquitous species has been repeatedly published in recent years and need not be repeated in the present connection.

This species was discussed and a number of illustrations were given in Knowlton's account of the Latah flora. ${ }^{5}$

s Knowlton, F. H., Flora of the Latah formation of Spokane, Wash., and Coeur d'Alene, Idaho: U. S. Geol. Survey Prof. Paper 140, p. 27, pl. 9, figs. 2, 7-9; pl. 01, fig. 2, 1926. 
The leafy twigs are sparingly represented at Grand Coulee. Associated with these are excellently preserved cone scales, which do not differ appreciably from those of the recent species of southeastern North America. One of these from Grand Coulee is figured on the accompanying plate.

There also occur in the Grand Coulee deposits staminate aments of Taxodium exactly like those that have proved to be so common in the Spokane region.

\section{Phylum SPERMATOPHYTA \\ Class ANGIOSPERMAE \\ Bubclass MONOCOTYLEDONAE \\ Order ARALES \\ Family ARACEAE \\ Genus LYSICHITON Schott \\ Lysichiton washingtonense Berry, n. sp. \\ Plate 11, Figure 2}

This species is based upon the impression of a tiny specimen which appears to represent parts of a crushed spadix of some aroid similar to or identical with Lysichiton. It shows the impression of the surface, which is seen to consist of small individuals (carpels?) closely packed and polygonal in outline, about 1 millimeter in diameter, highly convex distad, with a pronounced central umbilicus. The type and only specimèn is shown enlarged in the accompanying illustration.

The genus Lysichiton, the sole survivor of the Araceac in western North America, has but one or two existing herbaceous species, ranging from eastern Siberia through Alaska and western Canada to California and Idaho. It is unfortunate that more complete material of the fossil form is not available, but it must be considered to be a matter of extreme luck that even a fragment was preserved and discovered.

\section{Subclass DICOTYLEDONAE \\ Series CHORIPETALAE \\ Order JUGLANDALES \\ Family JUgLaNdaCEAE \\ Genus JUGLANS Linné \\ Juglans egregia Lesquereux \\ Plate 11, Figure 3}

Juglans egregia Lesquereux, Harvard Coll. Mus. Comp. Zoology Mem., vol. 6, p. 36, pl. 9, fig. 12; pl. 10, fig. 1, 1878.

Knowlton, in Lindgren, Jour. Geology, vol. 4, p. 889, 1896.

This species was described by Lesquereux from the auriferous gravel of California and was based upon a considerable amount of fairly complete material showing much variation in size and some variation in form, particularly respecting the obtuseness or pointedness of the base. As might be expected, the broader leaves are obtuse and the narrower acute, but such variations as have been observed are well within the limits of a single botanic species as illustrated among existing forms.

\section{Genus HICORIA Rafinesque}

Hicoria washingtoniana Berry, n. sp.

Plate 11, Figure 4

This species is based upon the single incomplete specimen figured. The material scarcely warrants an attempt at a diagnosis, but as it differs from the large amount of material of this age from Washington and Idaho which I have studied it seems worthy of record. The specimen is interpreted as a terminal leaflet of a large-leaved species of hickory, although it is not possible to be sure that Hicoria and Juglans have not been confused in this case as they have been in the past by other authors. The specimen indicates an ovate leaf about 16 centimeters in length and 6 centimeters in maximum width. The midvein is stout and prominent. The secondaries are relatively widely spaced, stout, diverging at angles of $45^{\circ}$ or slightly more, regularly ascending, and camptodrome. The tortiaries are indistinct but form an open areolation. The margins are beset with fairly large, uniform, closely spaced crenate teeth. The texture is fairly coriaceous.

Comparison of such incomplete material with either living or fossil species is worth little. In some respects it suggests the leaves of the Ternstroemiaceae, but it is larger and relatively wider than the members of this family in the western Miocene which I have referred to the genus Gordonia.

The genus Hicoria has been recorded in the Pacific region from the Miocene of Colorado, California, Spokane, Wash., British Columbia, and Oregon. It is, of course, present also in beds representing earlier horizons in this general region.

\section{Order SALICALES \\ Genus POPULUS Linné \\ Populus lesquereuxi Cockerell}

Populus heeri Lesquereux, The Cretaceous and Tertiary floras, p. 151, pl. 30, figs. 1-8; pl. 31, fig. 11, 1883. [Not Saporta.] Populus lesquereuxi Cockerell, Torrey Bot. Club Bull., vol. 33, p. 307, 1906; Colorado Univ. Studies, vol. 3, p. 172, 1906; Am. Naturalist, vol. 44, p. 44, fig. 8, 1910.

Knowlton, U. S. Nat. Mus. Proc., vol. 51, p. 261, 1916. Salix inquirenda Knowiton, U. S. Gcol. Survey Prof. Paper 140, p. 32 , pl. 11, figs. 1, 2, 1926.

Berry, U. S. Geol. Survey Prof. Paper 154, p. 242, 1929.

The Latah species named Salix inquirenda by Knowlton is represented by very large leaves at Grand Coulee and appears to me to be identical with the common Florissant form which Lesquereux determined as Populus heeri Saporta but which Cockerell has shown to be different from that European species. The extremely long and stout petiole, which is preserved in much of my material, is also confirmatory of the reference to Populus instead of to Salix. 


\section{Order Fagales}

Family FaGaCEAE

Genus QUERCUS Linné

Quercus mccanni Berry, n. sp.

Plate 11, Figures 5-7

Leaves lanceolate to obovate, with an abruptly pointed apex and a base that varies from cuneate to truncately rounded and in many specimens is inequilateral. Most of the specimens are preserved as impressions, but in the two or three that show something of the leaf substance the texture appears to have been subcoriaceous, though less so than in the associated species of oaks. Margin entire for a very short distance above the base; elsewhere with regular spaced and sized teeth. These increase regularly in size upward to the widest part of the leaf and then decrease toward the apex. They are usually oblique and rounded and are separated by rounded sinuses, the counterpart of the teeth in form. In one or two of the more elongated and narrower leaves the teeth are more ascending and pointed, and these leaves are very similar to those of Quercus horniana Lesquereux, of the Mascall formation of Oregon, but the Grand Coulee leaves are connected by insensible gradations with the round-toothed forms with which they are associated and undoubtedly represent a single botanic species. Petiole stout, expanding proximad, 1.2 to 2 centimeters in length. Midvein stout, prominent on the underside of the leaf, becoming thin distad. Secondaries medium stout, regularly spaced, and subparallel; their angle of divergence from the midvein depends on the width of the leaf, varying from $40^{\circ}$ to $60^{\circ}$; they are prevailingly straight, curving slightly distad and ending craspedodromely in the tips of the marginal teeth. The tertiary venation is quercoid, not prominent and seen with difficulty. Length 6.5 to 10 centimeters; maximum width, above the middle, 2.75 to 5 centimeters.

This characteristic species, which is named for F.W. McCann, president of the Coulee City Commercial Club, is obviously distinct from previously described forms, although it exhibits a certain resemblance to Quercus horniana Lesquereux, ${ }^{6}$ of the Mascall formation, Quercus spokanensis Knowlton, ${ }^{7}$ of the Latah formation, and Quercus clarnensis Trelease, ${ }^{8}$ of the Clarno formation. This resemblance is greatest between these species, which are narrower forms with more pointed and more ascending teeth, and the more elongate and narrow specimens of Quercus mccanni.

In all its features Quercus mccanni is exceedingly like the leaves of the chestnut oaks of southeastern North

\footnotetext{
6 Lesquereux, Leo, U. S. Nat. Mus. Proc., vol. 11, p. 17, pl. 5, fig. 6, 1888.

7 Knowlton, F. H., U. S. Geol. Survey Prof. Paper 140, p. 37, pl. 19, fig. 3, 1826.

8 Trelease, William, Brookjyn Bot. Garden Mem., vol. 1, p. 499, 1918.
}

America, and this agreement is so close that it would seem to indicate a close relationship and the former presence in the late Miocene of the West of a type of oak which subsequently became restricted to the East. $A$ second alternative is indicated by the resemblance of these leaves to those of the existing Quercus martensiana Trelease, of the eastern Sierra Madre, Quercus prinopsis Trelease, of the Mexican table-land, and Quercus chartacea Trelease, of the Cordilleran region of Mexico.

\section{Quercus simulata Knowlton}

Quercus simulata Knowlton, U. S. Geol. Survey Eighteenth Ann. Rept., pt. 3, p. 728, pl. 101, figs. 3, 4; pl. 102, figs. 1, 2, 1898; U. S. Geol. Survey Prof. Paper 140, p. 38, pl. 22, figs. $3,4,1926$.

Chaney, Walker Mus. Contr., vol. 2, No. 5, p. 168, pl. 12, fig. 1, 1920.

Berry, U. S. Geol. Survey Prof. Paper 154, p. 246, pl. 51, figs. 6, 7, 9-11, 1929.

Salix elongata Knowiton [not O. Weber], U. S. Geol. Survey Prof. Paper 140, p. 32, pl. 12, fig. 4, 1926.

Quercus chaneyi Knowlton, idem, p. 38, pl. 22, fig. 1, 1926. Quercus praenigra Knowlton, idem, p. 37, pl. 19, fig. 6, 1926.

This species was described by Knowlton from the Payette formation of Idaho and was identified by the same author from the Latah formation and by Chaney from the Eagle Creek formation. I have recently detected it in the Esmeralda formation of Nevada.

It is exceedingly common and variable in both the Payette and Latah formations. At Grand Coulse it is probably the most abundant species, and here again it shows its characteristic great variability both in form and in size. It ranges from narrowly to broadly lanceolate, with entire or sparingly toothed margins, either acuminate or bluntly tipped and with the base ranging from rounded to narrowly cuneate. Formerly I suggested comparisons with the existing Quercus hypoleuca Engelmann of the West or Quercus phellos Linne of the East.

I have subsequently had occasion to compare this and our other western Miocene oaks with the existing species of Mexico and Central America, with the result that I find a great similarity between Quercus simulata and a group of Mexican species, many of them shrubs or small trees, largely described in recent years by Trelease. These are Quercus actpulcensis Trelease, Quercus obscura Trelease, Quercus transmontana Trelease, Quercus viminea Trelease, and Quercus hypoleuca Engelmann, the last already mentioned in the preceding paragraph. All of these are forms of the western Sierra Madre. In addition Quercus mexicana Humboldt and Bonpland is also similar to the fossil form. This is a species of the Mexican table-land and adjacent cordillera. This resemblance between several of the oaks of the western Miocene and existing species of Mexico seems to be more than fortuitous, and I believe that it is of real significance. 


\section{Quercus treleasii Berry}

Quercus treleasii Berry, I. S. Geol. Survey Prof. Papcr 154, . p. 247, pl. 52, figs. 1-3, 1929.

This species is abundant in the Latah formation and also in the recent collections from beds assigned to the Payette formation of Idaho. It is represented at Grand Coulee by a single specimen. Like some of the associated oaks, Quercus treleasii shows similarities to several existing Mexican species. These are Quercus repanda Humboldt and Bonpland, a shrub of the Mexican table-land; Quercus chihuahuensis Trelease and its varieties, of the western Sierra Madre; and Quercus lecomteana Trelease and Quercus oleoides Chamisso and Schlechtendal, the first a shrub and the second a small tree, both found in the eastern Sierra Madre.

\section{Order ORTICALES \\ Family MORACEAE \\ Genus FICUS Linné}

Ficus interglacialis Hollick

Ficus interglacialis Hollick, New York Bot. Garden Jour., vol. 16, p. 44, pls. 152, 153, 1915; New York Bot. Garden Mem., vol. 7, p. 405, pls. 34, 35, 1927.

Equisetum, underground stem, Knowlton, U. S. Geol. Survey Prof. Paper 140, p. 24, pl. 9, fig. 1; pl. 26, fig. 5; pl. 29, fig. 8, 1926.

I am satisfied that the objects described from the Latah formation by Knowlton as underground tuberbesring stems of Equisetum are the same as those deseribed by Hollick from the St. Eugene silt of British Columbia as the fruits of a Ficus. They are present in the later collections from Spokane and vicinity and occur in the collections from Grand Coulee.

It is perhaps not possible to decide conclusively in fuvor of Hollick's identification, and a priori one would be more apt to expect Equisetum in the latitude and supposed environment than Ficus, especially as the abundant associated leaves referred to Ficus washingtonensis are not beyond suspicion. $\Lambda$ t the same time the axes have more the appearance of aerial stems than of rhizomes, and the supposed tubers, many of which are found detached, are conspicuously longitudinally ridged, entirely unlike any Equisetum tubers that I have seen, and I have seen a great many, both recent and fossil. On the other hand, they are similar to the fruits of a number of small hard spherical-fruited recent species of Ficus.

The specific name interglacialis was given because its author supposed that he was dealing with remains from an interglacial deposit, but for this there is no geologic or paleobotanic evidence.

\section{Order PLATANALES}

Family PLatanaceaE

Genus Platanus linné

Platanus, flower

Plate 12, Figure 1

Little that is definite can be said of this specimen, which appears to represent a flower of Platanus, leaves of two species of which are found in association with it. It shows a more or less flattened central base from which radiate masses of more or less discrete objects that are interpreted as flowers. What appears to be the peduncle is preserved for a length of nearly 5 centimeters, but of course the association may represent nothing more than superposition of the supposed flower head and a pine needle or leaf petiole.

\section{Order RANALES \\ Family MENISPERMACEAE \\ Genus CEBATHA Forskal \\ Cebatha heteromorpha (Knowlton)}

Populus heteromorpha Knowlton, U. S. Geol. Survey Prof. Paper 140 , p. 30 , pl. 12, figs. 8-10; pl. 13, figs. 1-7; pl. 14, figs. $1-3$; pl. 15, figs. 3-5, 1926.

Populus fairii Knowlton, idem, pl. 15, fig. 2; pl. 16, figs. 1-3. Cebatha multiformis Hollick, New York Bot. Garden Mem., vol. 7, p. 406, pl. 38, figs. 1-6; pl. 39, figs. 1-3, 1927.

Cissampelos dubiosa Hollick, idem, p. 408, pl. 37, figs. 4, 5 $(6,77)$; pl. 39, fig. 4.

This exceedingly variable species is the most abundant form in the Latah collections and is also found in the westward extension of this horizon in Grant County, Wash., and in the Payette of Idaho. It occurs in all sizes and shapes and shows a corresponding range of variation in its marginal characters. These have been sufficiently illustrated in the large suite of specimens figured by Knowlton and Hollick. As Knowlton suspected, the forms called fairii are not distinct from the type, but every gradation is represented, and leaves with three, four, or five primaries are not distinctive. Every locality in the recent collections that contains one contains the other. Hollick, in describing the flora from the St. Eugene silts of British Columbia, recognized the botanic affinity of these leaves but refrained from including Knowlton's supposed Populus of the Latah formation with the British Columbia material because he thought there was a great difference in age between the two outcrops. It has since been shown that the Latah is younger than Knowlton supposed it to be, and the evidence is fairly strong that the St. Eugene silts are much older than Hollick thought. 
The older paleobotanists referred to Populus a great many fossil leaves which show no relationship to that genus. Knowlton in his account of Populus heteromorpha recognized that it was unlike any existing Populus but convinced himself that it was a Populus because it resembled Populus arctica Heer of the early Tertiary, a species which I have shown is also not a Populus.

\section{Genus MENISPERMITES Lesquereux}

Menispermites latahensis Berry

Plate 12, Figures 4-6

Menispermites latahensis Berry, U. S. Geol. Survey Prof. Paper 154, p. 249, pl. 52, fig. 4, 1929.

Leaves relatively small, about as long as their maximum width, trilobate, with a wide central lobe and a pair of basal lateral lobes. Sinuses rounded, extending inward about halfway to the midvein. Margin with shallow, irregularly spaced dentate teeth, most prominent toward tip of central lobe and on the proximal side of the lateral lobes. Apex rounded. Tips of lateral lobes rounded, asymmetric. Base perfoliate. Texture thin. Length about 4.8 to 6 centimeters; maximum width, across lateral lobes, 5.25 to 8 centimeters. Petiole stout, presumably long, though preserved for only 1.25 centimeters. Primaries stout, diverging from the base at angles of about $45^{\circ}$ to $50^{\circ}$, the laterals curving outward to the tips of the lateral lobes. Secondaries numerous, ascending, indifferently camptodrome or craspedodrome according as the margin at their extremities is entire or toothed. Areolation large, polygonal.

This species was apparently not uncommon at Grand Coulee in late Miocene time, and the three specimens collected are about 50 per cent larger than the type material from Spokane, with which they agree perfectly in form and venation. They are not unlike some of the modern forms that American botanists refer to the genus Cebatha Forskal, which the Europeans generally include in the large genus Cocculus De Candolle. They are also similar to some of the forms referred to Menispermum Linné, which, as now restricted, includes an existing species in eastern North America and another in eastern $\Lambda$ sia. In view of the uncertainty of the generic affinity I prefer to refer the fossil to the form genus Menispermites, proposed by Lesquereux to fit just such cases.

Leaves of this family are common in the Upper Cretaceous of western North America but are extremely rare in the Tertiary of that region. The present species is not only a link with the past but also a link between eastern Asia and eastern North America, where its descendants still survive.

\section{Order ROSALES}

\section{Family GROSSULARIACEAE}

Genus RIBES Linné

Ribes fernquisti Berry

Plate 12, Figure 2

Ribes fernquisti Berry, U. S. Geol. Survey Prof. Paper 154, p. 251, pl. 63, fig. 21, 1929.

This species was described as follows:

Leaves relatively small, trilobate. Margin, except at base and in the sinuses, with coarse dentate teeth. Texture subcoriaceous. Length about 5 centimeters, as is also the maximum width. Apical lobe about as broad as it is long, bluntly pointed at apex. Base of the leaf truncate. Sinuses narrow and not deep. Primaries, three from the top of the petiole, stout and prominent. Secondaries stout, prominent, diverging from the primaries at acute angles. There are three or four subopposite to alternate secondaries in the central lobe, curved proximad and more straight distad, and craspedodrome. In the lateral lobes the basal secondary on the outside diverges close to the base and is relatively straighter and more prominent than its fellows and might be termed a subprimary. There is a second secondary on the outside below the basal secondary on the inside, and the latter is much curved, ascending inside the sinus margin and ending camptodromely if the margin is entire and craspedodromely if it has ascended to a point where there is a tooth on the margin. The primaries, particuarly the lateral ones, are slightly flexuous with respect to the alternate divergence of the secondaries. The tertiary branches from the distal parts of the secondaries are well marked, and the ultimate ones are usually craspedodrome. Internal tertiaries are transverse and percurrent or inosculating in the middle region. The areolation is an open mesh that agrees precisely with that in leaves of existing members of the genus.

The single specimen detected in the collections from Grand Coulee is still smaller than the type material, measuring 2.5 centimeters in length and 2.6 centimeters in maximum width. Otherwise it is identical with the material from Spokane.

Ribes has not often been recognized in the fossil state. Two species have, however, been recorded from Florissant, Colo., but both of these are unlike the Latah form. There are over 60 existing species of Ribes, all shrubby and widely distributed in the North Temperate Zone and in the Andes of South America. Fully 50 species are known from North America.

\section{Family HaMaMELIDACEAE \\ Genus LIQUIDAMBAR}

Liquidambar, fruit

Liquidambar, fruit, Knowlton, U. S. Geol. Survey Prof. Paper 140, p. 42, pl. 10, fig. 10, 1926.

Knowlton described and figured a rather well preserved fruit from the Latah formation at Spokane and suggested its probable relationship to the associated 
leaves, which he identified as Liquidambar pachyphyllum Knowiton but which I regard as simply a variant of the common Miocene Liquidambar californicum Lesquereux. Subsequently additional fruits have been collected from the Latah formation. I have no doubt that these fruits belong to this species.

The material from Grand Coulee is especially interesting, as there are no traces of leaves in the collection and over a dozen of the fruits. In several specimens more or less of the peduncle is preserved. This is unusually stout, and in one small specimen in which it appears to be complete it is only 4 centimeters in length. The presence of fruits and no leaves may be explained as due to water transportation of the material, for the fruits are dry when shed and readily float, and the leaves decay in water more rapidly than leaves of most other genera.

\section{Order GERANIALES}

Family RUTACEAE

Genus PTELEA Linne

Ptelea miocenica Berry, n. sp.

Plate 12, Figure 7

Samara broudly winged, subcircular in outline, emarginate at both the apex and base. Peduncle slender, incomplete, preserved for a length of about 6 millimeters. Seed cavity fusiform, widest above the middle and more tapering proximad than distad. It has the appearance of being 2-celled. Length about 1 centimeter; maximum width about 6 millimeters. The whole, including wing, about 1.75 centimeters long aqd 2.4 centimeters in maximum width. The wing is thin but of firm consistency and is faintly radiately reticulate veined.

This characteristic fruit is very close to that of the existing Ptelea trifoliata Linné and is the first representative of this genus found fossil on the Pacific slope. The genus makes its appearance in the lower Eocene of the Mississippi embayment and is sparingly represented in the geologic record. $\Lambda$ Miocenc species based upon the trifoliate leaves has been recorded from Florissant, Colo., ${ }^{9}$ and it is quite possible that the present fruit represents the same botanic species as the leaves found at Florissant. The genus is not uncommon in the Miocene of Europe.

Ptelea has four or five existing species of shrubs or small trees confined to the United States and Mexico, ranging northward to southern Ontario and westward to Colorado and New Mexico.

- Cockerell, T. D. A., Am. Mus. Nat. Hist. Bull., vol. 24, p. 98, 1908.
Order SAPINDALES

Family ACERACEAE

Genus ACER Linne

Acer merriami Knowlton

Plate 13, Figure 13

Acer merriami Knowlton, U. S. Geol. Survey Bull. 204, p. 74, pl. 14, fig. 7, 1902; U. S. Geol. Survey Prof. Paper 140, p. 45 , pl. 28, fig. 1, 1926.

The maples from the western Miocene are in a state of confusion, too many species have been described, and specific names have also usually been given to the detached fruits. The present specimens are referred to Acer merriami because they are decidedly 3-lobed and have but three primaries, although I do not regard either of these features as good specific characters. The specimen figured differs from the type in the narrower lateral lobes, in consequence of which the base is cuneate instead of cordate, a very simple variation and of no specific value. In this last feature it resembles the leaf from the Latah formation which Knowlton referred to this species.

\section{Order RHAMNALES}

Family RHAMNACEAE

Genus PALIURUS Jussieu

Paliurus hesperius Berry

Plate 13, Figures 1-5

Paliurus hesperius Berry, Am. Jour. Sci., 5th ser., vol. 16, p. 40, figs. 1-3, 1928; U. S. Geol. Survey Prof. Paper 154, p. 257, pl. 57, fig. 1, 1929.

It was my original intention to describe the leaves and fruits of this Paliurus as separate species. The fruits were discovered and described in 1928, after the manuscript for my revision of the Latah flora (Professional Paper 154-H) had been prepared, and in the proof of that paper (published in 1929) the name given to the fruit was used for the leaves without any description of the fruits, a citation to the earlier description being inserted. As leaves and fruits are associated at Spokane and at Grand Coulee, nearly 100 miles west of Spokane, it is a reasonable conclusion that both belong to the same botanic species. Under the circumstances the collective species should be redescribed.

Leaves of medium size, broadly ovate, widest below the middle; the apex pointed but not extended; base broadly rounded or slightly cordate. Texture subcoriaceous. Margins with closely spaced, prevailingly 
small, crenate tecth. Length about 7 centimeters; maximum width about 4.5 centimeters. Petiole not preserved. Midvein stout, prominent. Lateral primaries diverge from the base at acute angles; these are as stout as the midvein and curve upward and barely escape being acrodrome by uniting with short secondaries from the distal part of the midvein. The lateral primaries give off on the outside several camptodrome secondaries. The areolation is a fine mesh indistinctly preserved.

These leaves are not uncommon in the Latah formation at Spokane; they occur sparingly at Grand Coulee and also in the Payette formation of Nez Perce County, Idaho, about 85 miles east of south of Spokane.

The fruits are discoidal, peltate, pedunculate; the essential part depressed turbinate, the margin extended horizontally as a broad scarious, veined wing.

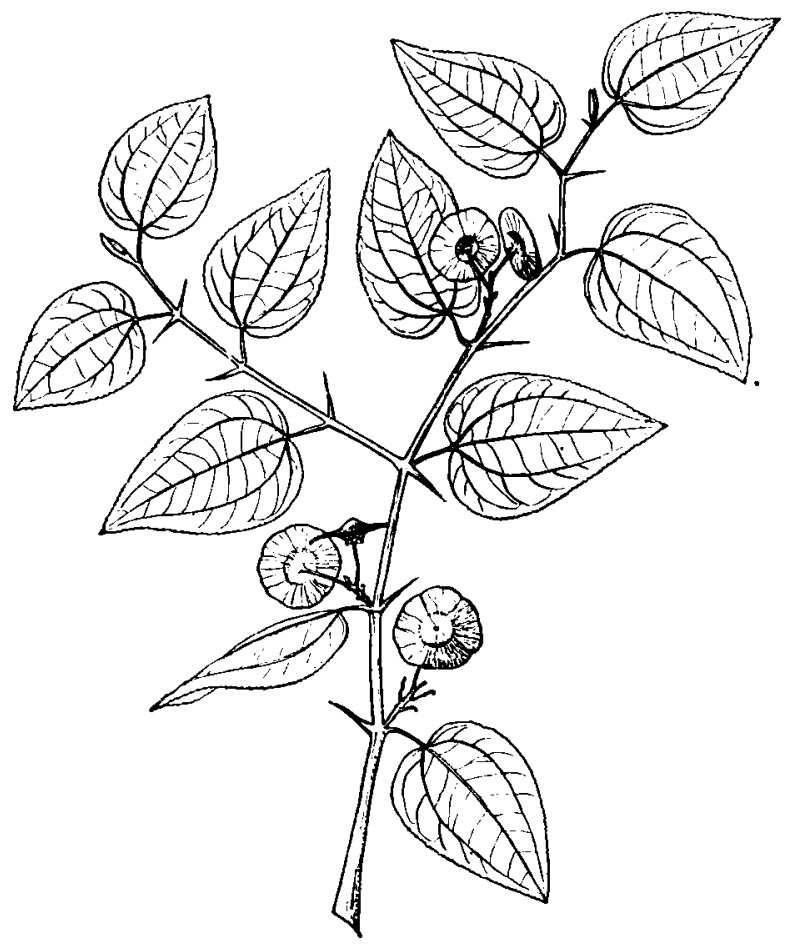

Fluble: 3. Restoration of I'aliurus hesperias

The wing margin is irregularly sinuate. The veins are radial in direction, are slightly undulate, and may be simple or once or twice forked.

$\Lambda$ s preserved the whole fruit departs slightly from circular in outline, being about 1.2 by 1.6 centimeters in diameter. The type comprises two specimens that are counterparts, split in the plane of the wing, which is well preserved. The fruit substance is gone in the central part of both specimens and was probably lost when the specimen was split open, as one counterpart shows the cast of the apical umbo above the wing and the other shows a cast of the proximal part below the wing. These are slightly deformed by pressure during fossilization but preserve the details in a remarkable way and have served for the reconstructed median longitudinal section shown in the accompanying Fig- ure 3. Figure 1 on Plate 13 shows the fruit viewed from below pressed down over the peduncle, which is seen projecting below the wing margin. In the center is the cast of the rounded apex, with a prominent conical tip from which impressions of the veins radiate. The impression is darkened around the margin of the umbo, where the substance is preserved at the inner margin of the wing.

The counterpart is similar except in the center, where the deep cast of the conical part of the fruit below the wing, somewhat offset, is preserved. This shows clearly the collar around the upper expanded end of the peduncle and the scar where its distal end was attached to the base of the fruit. The material is almost as good as a recent Paliurus fruit and is much better for having the resistant substance of the fruit proper gone, because both surfaces can be studied, one of which would have inevitably been concealed had it not dropped out when the clay was split. The foregoing description is based upon the type specimen. Subsequently several somewhat smaller specimens have been collected from the same locality as well as from the Latah formation in the brickyard exposure at Spokane. A restoration of the species is attempted in the accompanying text figure.

The fossil agrees with the fruits of the recent species of Paliurus in every feature except that it is slightly smaller, in this respect being closest to the extising I'aliurus aculeatus Lamarck, although the' existing forms show considerable variation in the size of their fruits, and I have not enough material to be sure of the limits of variation in either the existing or the fossil forms. The fruits of Paliurus aculeatus which I have seen are more robust, with a larger essential part, which is much more massive proximad below the wing, thicker wings, less visible venation, and shorter peduncle. The fossil is more like the fruits of Paliurus orientalis Franchet that $\mathrm{I}$ have seen, in relative proportions, in the thinner wing with greater visibility of the veins, and in the relative length of the peduncle. No leaves are associated with the fossil, but at approximately the same horizon both at Grand Coulee and in the Latah formation at Spoliane there are leaves of a Paliurus which are nearer to Paliurus orientalis than they are to the other existing species. It is very probable that leaves and fruit represent the same Miocene species, but this can not yet be demonstrated.

The genus Paliurus of Jussieu contains two or three existing species of shrubs or small trees with cordate or ovate, palmately 3-veined, usually small leaves with stipular thorns. The fruits are coriaceous, peltate, umbonate, with a horizontal marginal radiately veined wing. In existing floras they are restricted to dry-soil habitats from Spain on the west to Japan on the east. Paliurus aculeatus Lamarck extends from Spain through southern Europe, Asia Minor, Crimea, the Caucasus, and Persia to China (Szechwan). Paliurus ramosissimus Poiret extends from about $27^{\circ}$ 
north latitude in Kiangsi to Japan, and Paliurus orientalis Franchet, sometimes united with the preceding, reaches the stature of a thin tree sometimes 50 feet tall in eastern Szechwan and Shensi, China. Whatever the taxonomic distinction of the three, the ranges overlap, and the geologic record is sufficiently complete to show that their present range is a restricted one and that they represent relict species.

Turning now to the geologic record, we may note that a considerable number of fossil species have been described, based for the most part on leaves and therefore subject to the uncertainties attending the identification of remains of this class. The oldest records embrace 13 species, so called, of leaves from the Upper Cretaceous. These include four from the Dakota sandstone of Kansas, one from the Patoot beds of Greenland, two from the Mill Creek beds of western Canada, one from Vancouver Island, one from the Eutaw formation of Georgia, three from the Magothy formation of New Jersey and contemporaneous beds on Staten and Long Islands, and one from the so-called "Laramie" of Yellowstone Park. Many of these are very similar to the leaves of the existing species but lack the corroboration of associated fruits or structural remains.

The Eocene has furnished at least 10 nominal species, including occurrences in western Greenland, Svalbard (Spitzbergen), Siberia, and Alaska on the north and in British Columbia, Montana, Colorado, and Wyoming in the western part of North America. I have described three species from the Wilcox group (lower Eocene) of the Mississippi embayment, and one of these is represented by characteristic fruits. ${ }^{10}$ Seward ${ }^{11}$ has described a large fruit from the supposed Eocene of southeastern Nigeria which has the appearance of a Paliurus but which is not certainly such.

The Oligocene contains at least three species-one from Louisiana represented by very characteristic leaves and thorny stems and two from southeastern France represented by both leaves and fruit.

At least 13 nominal species have been recorded from the Miocene. These include identifications based upon leaves from Alsace, Switzerland, Bohemia, Italy, France, Silesia, and two from Florissant, Colo., the last not conclusive in themselves but highly probable in view of the occurrence of typical fruits at the same Miocene horizon in the State of Washington. Miocene species based upon fruits include occurrences in Bohemia and Styria, ${ }^{12}$ Switzerland, ${ }^{13}$ and southern Russia. The last, which comes from the Sarmatian stage, is scarcely if at all distinguishable from the existing Paliurus aculeatus. ${ }^{14}$ The Pliocene record con-

ju Berry, E. W., U. S. Geol. Survey Prof. Paper 91, p. 279, pl. 71, fig. 4, text fig. $14,1916$.

11 Seward, A. C., Nigeria Geol. Survey Bull, 6, p. 75, pl. 1, fig. 5, 1924.

12 Ettingshausen, C. yon, Die fossil Flora des Tertiïr-Beckens von Bilin, pt. 3, p. 39, pl. 50, figs. 6, 7, 1669 .

13 Heer, Oswald, Flora tertiaria llelvetiae, vol. 3, p. 76, pl. 122, figs. 27-39, 1859.

"Kryshtofovich, A., Acall. im]. sei. St.-Pátersbourg Hull. 9, [1. 692, pl. 1, fig. 1. sists of a typical fruit from central France (Cantal), which is also indistinguishable from the existing Paliurus aculeatus. ${ }^{15}$

In view of what we know of the plant history of the Tertiary it is surely of interest that the Miocene species from Washington should be most similar to the restricted species of south-central China ( $P$. orientalis), as are also the leaves associated with the fruit, and that there should be earlier (late Eocene) species in the intervening region in Alaska and Siberia.

\section{Family VITACEAE \\ Genus VITIS Linné \\ Vitis bonseri Berry, n. sp. \\ Plate 13, Figure 6}

$\Lambda$ very characteristic seed. Somewhat compressed, broadly obovate in profile, stoutly obtusely pointed at the base, broadly rounded above. Hilum large and circular midway between the apex and the base; raphe narrow. Testa thin. Length 4.25 millimeters; maximum width 3.5 millimeters. The single specimen is split medially, and the type consists of the original and counterpart, which show the opposite sides of the seed viewed from within.

In size and form the fossil is indistinguishable from the seeds of a number of existing species of Vitis, so that comparisons are without significance.

The occurrence of these characteristic seeds is of considerable interest because no leaves of this genus are associated with them; in fact, except for very doubtful leaf material from the Latah formation at Spokane and equally doubtful material from Contra. Costa County, Calif., the only Miocene occurrences of Vitis recorded from western North America are two snecies from Florissant, Colo. The genus is considered by Knowlton to be present in the late Upper Cretaceous of New Mexico and Wyoming, and several species have been recorded from the early Tertiary of the western United States, British Columbia, and Alaska. None have been recognized in eastern North America in beds earlier than the Pliocene Citronelle formation of Alabama.

\section{Order PARIETALES \\ Family TERNSTROEMIACEAE \\ Genus GORDONIA \\ Gordonia hesperia Berry}

Plate 13 , Figures 7,8

Gordonia hesperia Berry, $\Lambda \mathrm{m}$. Jour. Sci., vol. 18, p. 430, figs. $1,2,1929$.

Although the specimens of this species from Grand Coulee are relatively shorter and wider than the specimens figured from the Latah formation at

${ }^{15}$ Iangeron, Maurice, Soc. hist. nat. Autun Bull., vo]. 15, p. 85, pl. 6, text fig. 1, 1902 
Spokane, the abundance of material from the Spokane locality shows that they fall within the limits of variation of the species.

It is an interesting fact, already discussed in the paper above cited, that our northwestern Miocene contains two species of Gordonia based upon leaves and two based upon seeds and that the latter are more similar to existing Asiatic species than to the existing species of southeastern North America.

\section{Order UMBELLALES \\ Family CORNACEAE \\ Genus NYSSA Linné \\ Nyssa hesperia Berry, n. sp. \\ Plate 13, Figures 9-11}

Stones of medium size; prolate spheroidal or slightly compressed in form, widest medially and about equally rounded at both ends, with about 10 prominent wide rounded ribs separated by narrow deep sulci. About 1.5 centimeters or slightly less in length and about 7.5 millimeters in diameter. All the specimens collected are preserved as casts in the clays, and they show various degrees of flattening. The type comes from the brickyard exposure of the Latah formation, but they are also not uncommon in the Miocene deposits of Idaho usually referred to the Payette formation. They are very much smaller, more rounded at the ends, and with fewer ribs than Nyssa magnifica (Knowlton) Berry ${ }^{16}$ of the Latah formation. They are associated with the leaves described as Nyssa knowltoni Berry ${ }^{17}$ both in the Latah and in the Payette.

The stones of Nyssa are very abundant in the earlier Tertiary of North America, a great variety having been described from the Eocene lignites of

${ }^{16}$ Berry, E. W., U. S. Geol. Survey Prof. Paper 154, p. 261, 1929.

${ }^{27}$ Idew, p. 201, pl. 59, fig. 7.
Brandon, Vt., but for some reason they are much rarer in the later Tertiary, where we know only this and one other species from the Latah and its equivalents and a third species from the Miocene Calvert formation of Virginia. Only two American Miocene species ba'sed upon leaves are known-the one mentioned above and a second from the Eagle Creek formation and the Bridge Creek shales of Chaney in Oregon.

Species of Nyssa based upon the stones alone are always of doubtful specific distinctness, and I might mention a great many so-called species of stones from other and very different horizons, both in this country and abroad, which resemble the present species, but such comparisons lack any real value.

\section{POSITION UNCERTAIN}

Phyllites couleeanus Berry, n. sp.

Plate 13, Figure 12

This single specimen seems to me so obviously to represent an abnormal leaf that I have not ventured to attempt a determination. It is elliptical in general outline, about 6.5 centimeters long and 4 centimeters in maximum width. Apex rounded truncate. Base cuneate. Margins entire for their lower twothirds; above with a few subequal prominent toeth. Midvein stout and prominent. Secondaries nine or ten pairs, medium stout; the basal diverge at wide angles approaching $90^{\circ}$ and become progreseively more ascending upward, the angle of divengence in the tip being about $45^{\circ}$. The lower four or five secondaries are camptodrome; the remainder are crespedodrome, ending in the teeth. The tertiaries are indistinct.

My belief is that this leaf is an abnormal leaf of some oak, quite likely the common form at this outcrop which I have described as Quercus mccanni. 


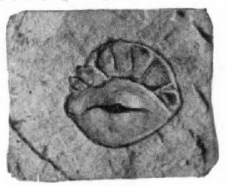

1
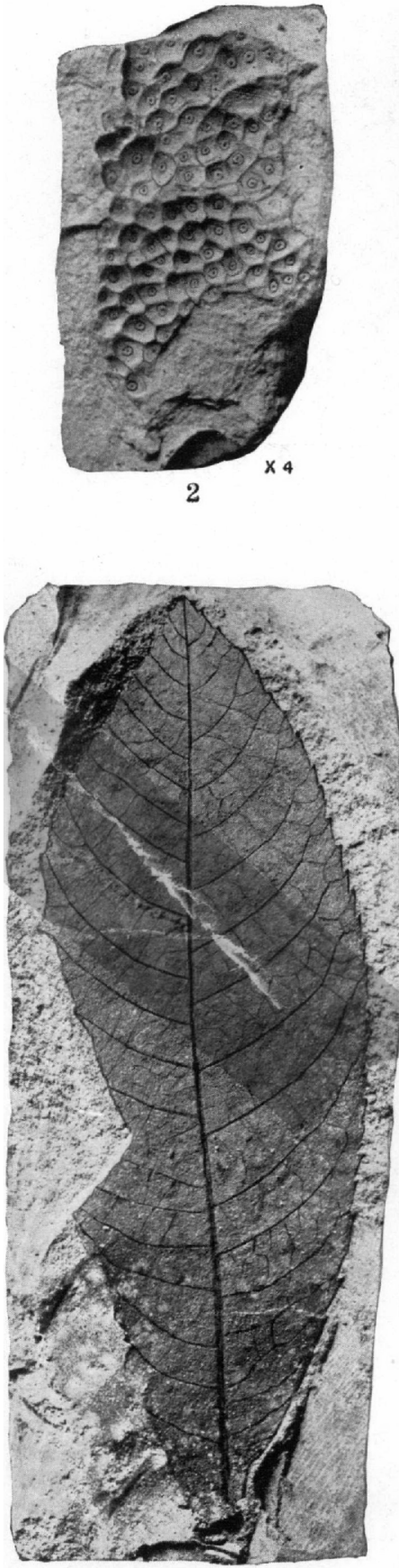

3
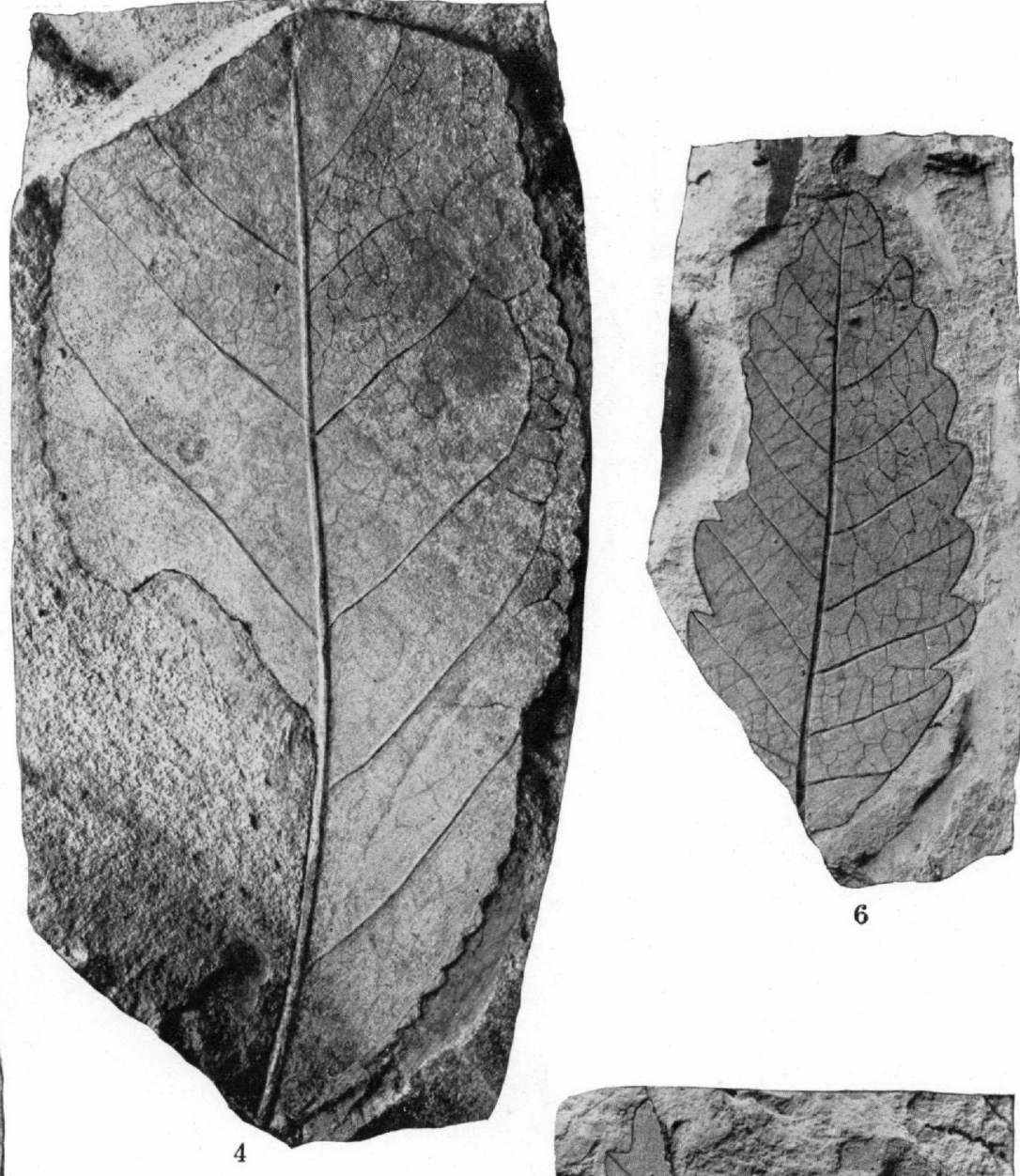

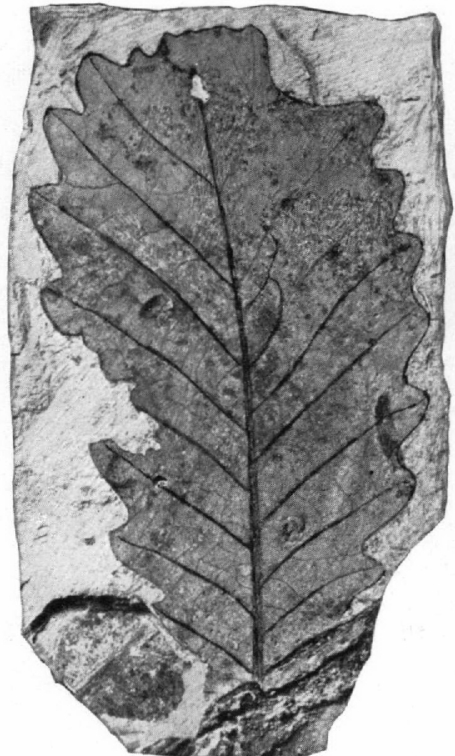

5

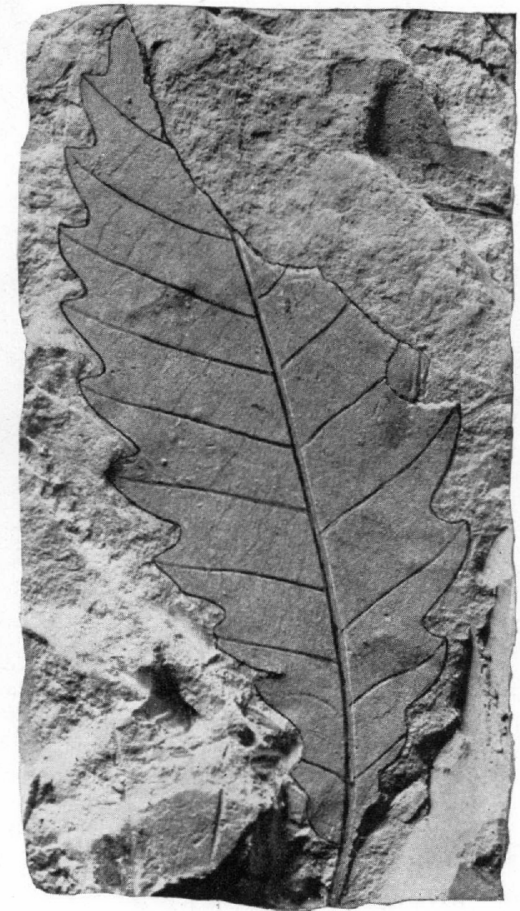

7
MIOCENE FLORA FROM GHAND COULEE, WASH.

1. Cone scale of Taxodium dubium (Sternberg) Heer.

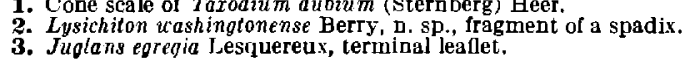

4. Hicoria washingtoniana Berry, n. sp., terminal leaflet. 
L. S. GEOLOGICAL SERVEY
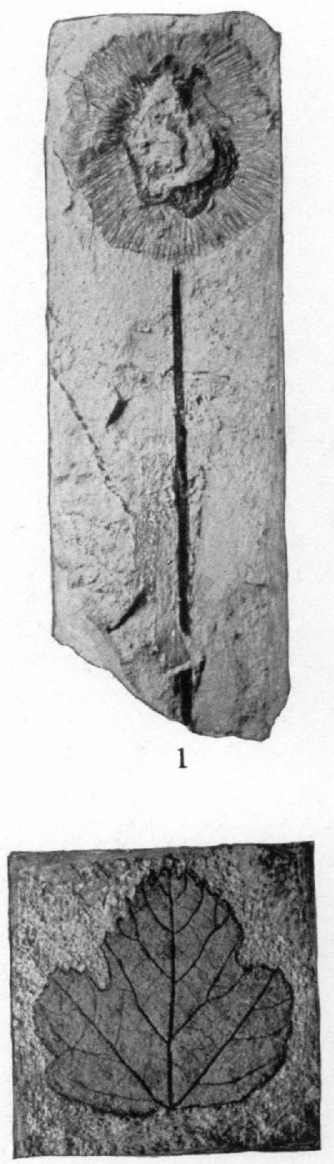

2

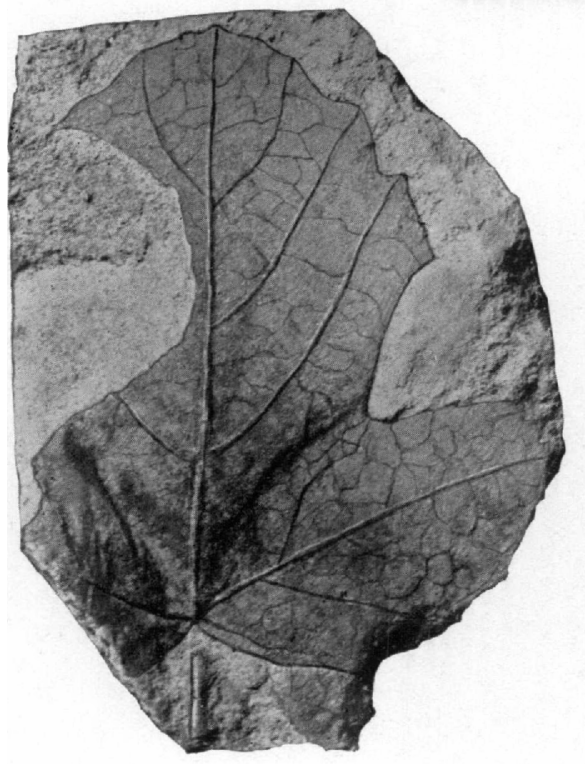

4

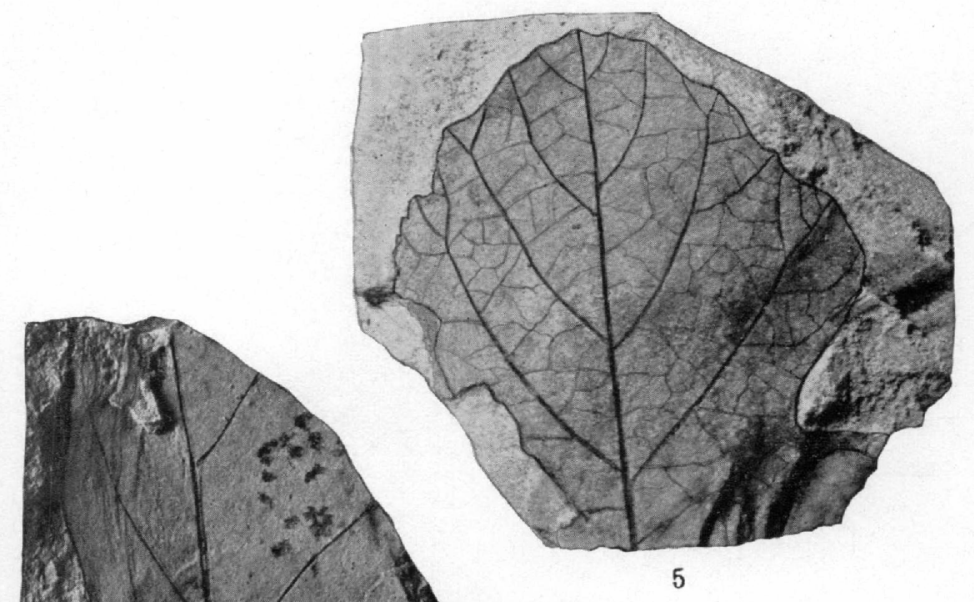

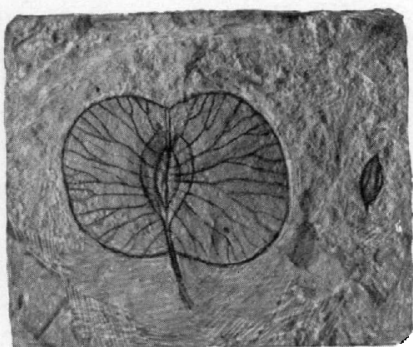

7

3

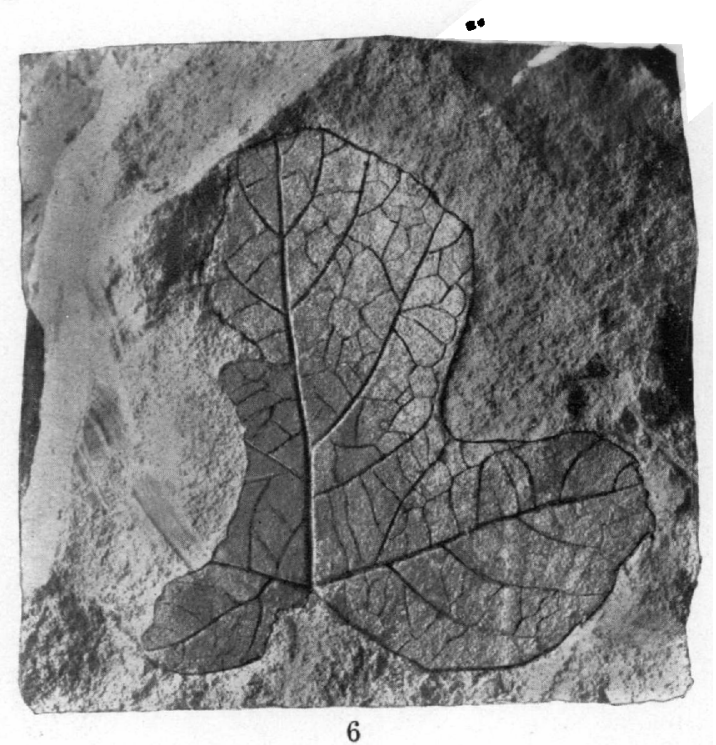

6

1. Flower head of Platanus.

3. Quercus cognatus Know lton, fragment with leaf spot fungi.

MIOCENE FIOHA FROM GRAND COULEE, WASH.

4-6. Nenispermites latahensis Berry.
7. Ptelea miocenica Berry, n. sp. 

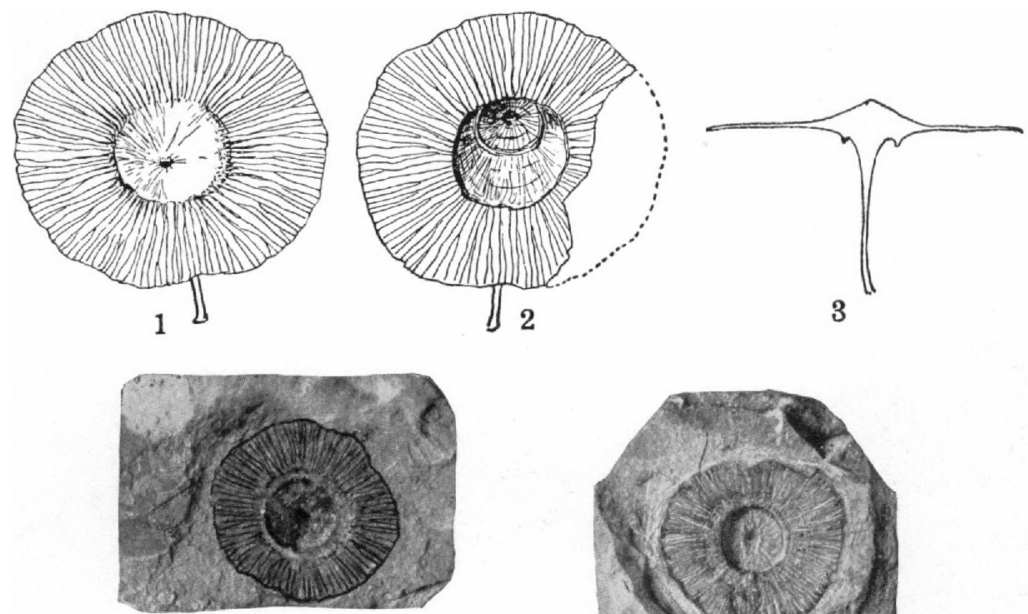

4

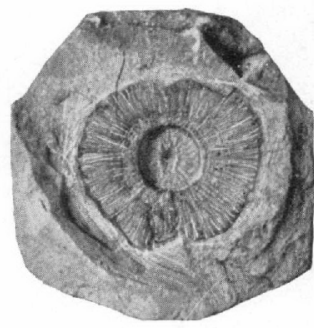

5
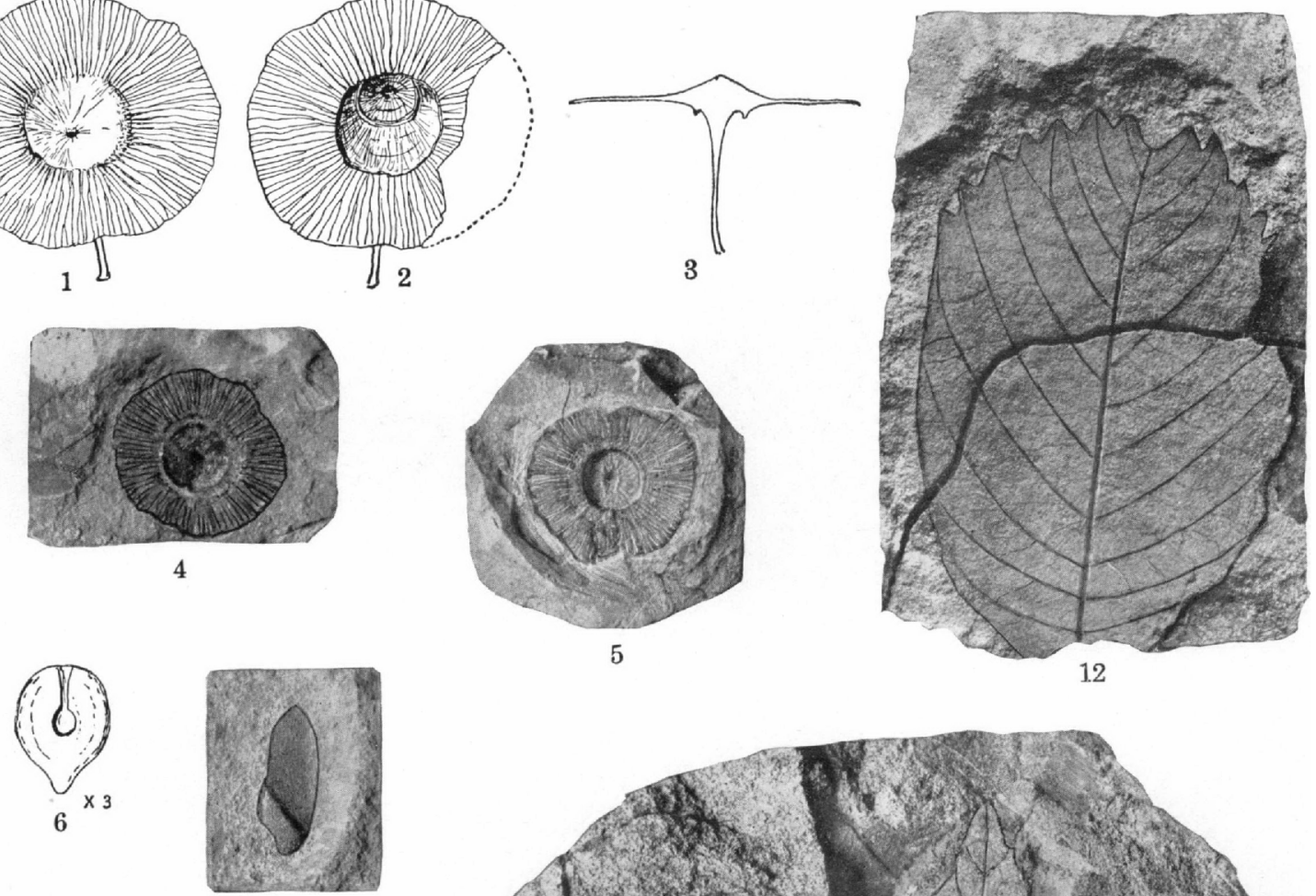

1.2

7

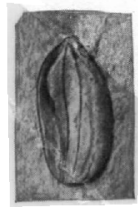

9

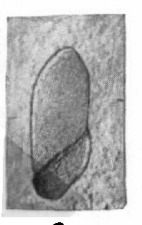

8

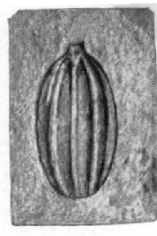

10

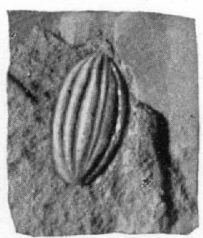

11

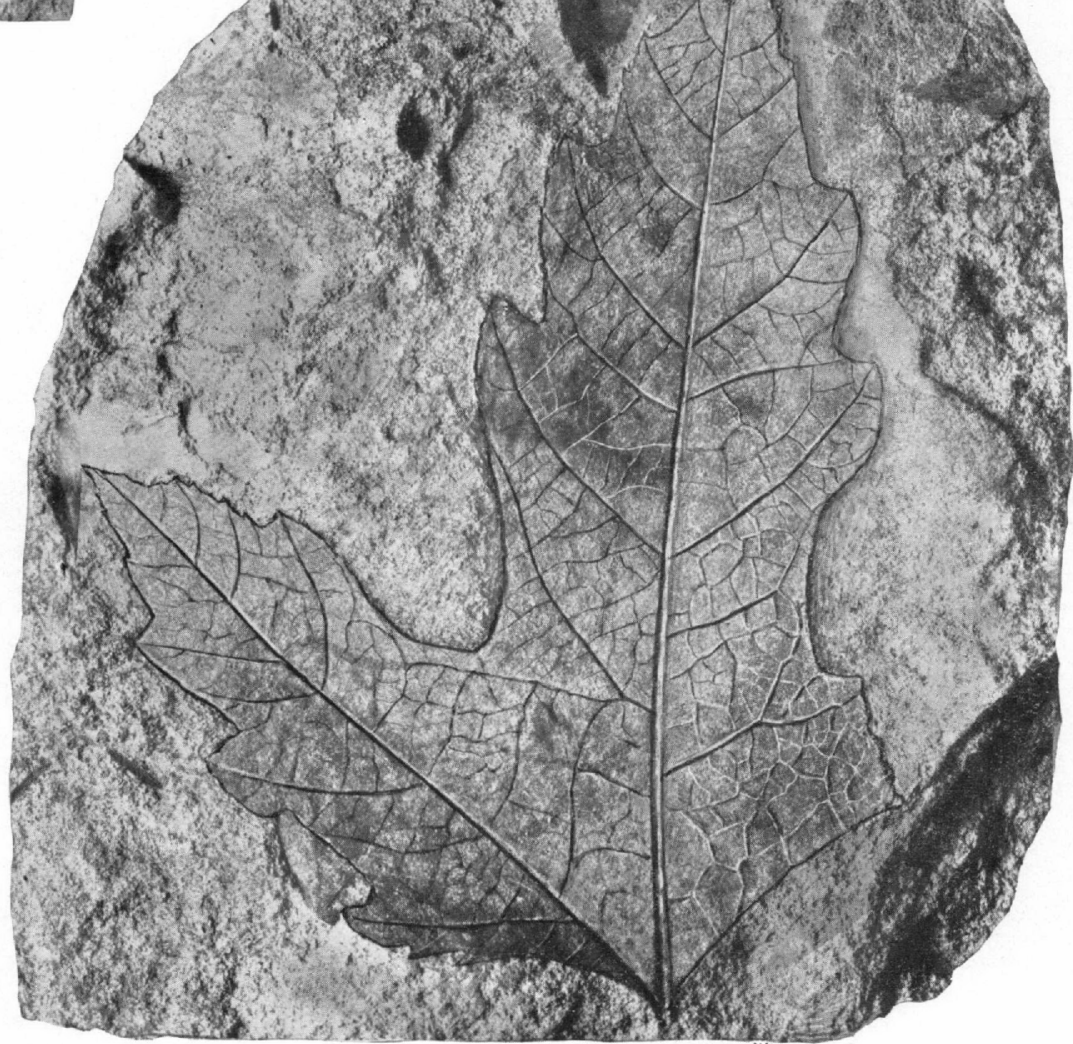

13

MIOCENE FLORA FROM GRAND COULEL, WASH.

1-5. Paliurus hesperius Berry. 1, 2, Opposite vieu's of the type; 3, side view restored; 4, 5 , photographs of smaller specimens. 6. Vitis bonseri Berry, n. sp., seed, inside view. 7. 8. Gordonia hesperia Perry.
9-11. Nyssa hesperia Berry, n. sp. 9, 10 from Grand Coulee; 12. Phyllites conleeana Berry, n. sp. 13. Acer merriami Knowiton. 


